Research Article

Open Access

Tatjana Timofejeva*, Guna Svence, Ala Petrulite

\title{
Theoretical and Practical Study of the Concept of Social and Emotional Health by Michael J. Furlong Applied to the Selection of Teenagers and Youth
}

DOI 10.1515/ sigtem-2016-0019

\begin{abstract}
Based on the analysis of scientific research, it has been concluded that the methodology 'Social Emotional Health Survey - Secondary' (SEHS-S) with meta-construct of covitality is a universal tool in order to define the social and emotional health of teenagers and young people; it has also been found that the meta-construct of covitality is essentially related to other psychological constructs, such as emotional intelligence, vitality, social competence and mental health. In the research that was conducted in Riga Teacher Training and Educational Management Academy (Timofejeva, 2015), the method of M.J. Furlong has been adapted to the Russian language, Latvian language interpretation of the notion of covitality has been proposed offering terms 'Sociāli emocionālās veselības faktors' or SEV (social and emotional health factor) or 'sinergiskā vitalitāte' ('synergic vitality'). Furthermore, a theoretically constructive model of the author has been created. Within this model, a new correlation has been hypothetically predicted between meta-construct of covitality (SEV-factor) and other scientifically acknowledged psycho-social constructs and notions: psycho-social prerequisites of the SEV factor and psychological options that depend on the level of the SEV factor. During the research, a selection of several teenagers and young people - students of comprehensive schools of Riga - with Russian as their native language was made $(n=184)$. It was found that the applied methodology is valid for the selection of Russian-speaking teenagers/youth of Latvia and that it can be recommended to the psychologists of schools as a new psychometric tool for their professionally practical duties. The data obtained within the research is planned to be used for comparisons with a similar research conducted in Lithuania (Lithuanian University of Educational Sciences), led by doc. A. Petrulytè.
\end{abstract}

Keywords: social and emotional health, the age phase of teenagers/youth, emotional intelligence, vitality, social competence.

\section{Introduction}

In accordance with the common priority aims of World Health Organisation (WHO) and American Psychology Association (APA) towards monitoring the social and psychological health of the young generation (Furlong, 2015), for the past 10 years, Prof. Michael J. Furlong (director of the Center for School-Based Youth) has been leading theoretical and practical researches in the University of California (Santa Barbara) that strive to create and implement usage of a universal and convenient psychometric tool (test) for predicting the social

*Corresponding author: Tatjana Timofejeva, Riga Teacher Training and Educational Management Academy, Latvia, E-mail: timofeeva1501@gmail.com

Guna Svence, Riga Teacher Training and Educational Management Academy, Latvia

Ala Petrulite, Lithuanian University of Educational Sciences, Lithuania 
and emotional health of the teenagers and youth. During this research work, a methodology, intended for testing teenagers and youth in schools, named 'Social Emotional Health Survey' was created.

The methodology was piloted in the USA, Australia, Japan, South Korea, Turkey, Peru and other states (Furlong, 2015; You et al, 2015). Therefore, in order to obtain information about the situation of social and emotional health of teenagers and youth in Baltic states, Michael J. Furlong and Prof. Ala Petrulyte (Lithuanian University of Educational Sciences) are already collaborating in their research effort. Michael J. Furlong is showing an interest in piloting and practically using the methodology 'Social Emotional Health Survey - Secondary' (SEHS - S) in Latvia. Thus, this particular research is to be considered as a part of an international cooperation.

\section{Aim of the Study}

The aim of the research is to perform a theoretical and practical study of M.J. Furlong's social and emotional health concept, 'Social Emotional Health Survey - Secondary' (SEHS-S) with its meta-construct of covitality and other constructs related to it.

\section{Materials and Methods}

Within the research, the following theoretical and empirical questions are highlighted:

1. What is the essence of the tool for M.J. Furlong's social emotional health 'Social Emotional Health Survey - Secondary' (SEHS-S) concept, privilege and possibilities for application?

2. With what kind of other psychological health indicators is the M.J. Furlong's concept connected?

3. What are the linguistic first stage adaptation validity indicators of M. J. Furlong's social emotional health research tool 'Social Emotional Health Survey - Secondary' (SEHS-S) in Latvia?

4. Is there an important mathematical, statistical difference between various teenager and youth social demographical groups, using the indicator from M.J. Furlong's method of 'Social Emotional Health Survey - Secondary' (SEHS-S)?

M.J. Furlong's research concept on 'Social Emotional Health Survey - Secondary' (SEHS-S) and results of a similar theoretical analysis and a creation of theoretical author model (Timofejeva, 2015) about covitality (SEV factor) been used in this research in Latvia. The following empirical research procedure was used: the first stage of linguistic adaption of the method 'Social Emotional Health Survey - Secondary' (SEHS-S) has been carried out in Latvia in three stages: stage 1 - respondent focus group $(n=20)$ survey; stage 2 - respondent main selection $(n=184)$ survey; stage 3 - data processing, using quantitative data research methodology.

For statistical processing, a special program SPSS (Statistical Package for the Social Science for Windows) was used: Descriptive statistic; Non-parametric Mann-Whitney criterion - importance of difference evaluation between two independent variables (group); One-factor dispersion analysis (ANOVA) - importance of difference evaluation between three or more independent variable (group) average values. The control of the validity and credibility of the methodology 'Social Emotional Health Survey - Secondary' (SEHS-S) was tested. To make the psychometrical tool approbation effective, a focus group survey was made. For this survey, a random selection was made of 20 respondents in the age group 12-18 and from various schools of Riga (approximately 10\% of the entire research group). Considering that the selected pupil's native language is Russian, the original content of the methodology 'Social Emotional Health Survey - Secondary' (SEHS-S) was translated from English to Russian. The translation procedure consisted of following translation stages:

1. The translation from English to Russian by a philologist (native Russian speaker);

2. The translation from psychologist's point of view by the research author (native Russian speaker);

3. The creation of appropriate text for the questionnaire together with a psychologist from academic high school. 
4. The evaluation by an independent psychologist (native Russian speaker);

5. Terminological specification of the language conformity with the language use in the original of the methodology.

After the survey of the focus group, a psychometrical check of the test translation's psycholinguistic conformity was conducted. In essence, the investigated methodology is a self-assessment test that contains 36 statements, each of which needs to be answered to what extent a statement corresponds with the respondent's own feelings: from minimum to maximum, according to the scale of 1-4 or 1-5 points. All 36 test questions are grouped by three according to 12 initial psychosocial concepts. These 12 concepts are united in four first-order constructs: Belief in Self, Belief in Others, Emotional Competence and Engaged Living, which together form covitality, the synergetic, second-order meta-construct (Furlong, 2015). As survey includes five grids, and each scale's coherence was controlled (see Table 1).

Table 1. Cronbach's alphas indicators for focus group

\begin{tabular}{ll}
\hline Constructs & Cronbach's alpha \\
\hline Belief in Self & 0.64 \\
Belief in Others & 0.76 \\
Emotional Competence & 0.81 \\
Engaged Living & 0.90 \\
Covitality (SEH factor); & $\mathbf{0 . 8 0}$ \\
Mean - 110,70; SD - 12,72 & \\
\hline
\end{tabular}

As seen in Table.1, the statement coherence indicator in the translation of the methodology to Russian is sufficient to make this translation reliable and use it in the following research stage. The examination of methodology 'Social Emotional Health Survey - Secondary' (SEHS-S) in the main selection survey of the research: teenagers and youths of 12-18 years, whose native language is Russian, and pupils from various educational places in Riga participated in the research. In November 2015, a survey spread over three weeks was done in four different schools in the region of Riga's city (A, B, C, D), which were selected randomly. The total amount of respondents were $n=184.88$ respondents (47.8\%) were boys; 96 respondents $(52.2 \%)$ were girls. 12-18-year-old respondents participating in the research, were split in three groups: 12-13 years old -59 respondents, 32.1\% (young teenage years); $14-15$ years old - 53 respondents, $28.8 \%$ (older teenage years); $16-18$ years old -72 respondents, $39.1 \%$ (early youth). Pupils from the following grades participated in the survey: School A: grade 8, 9 and 12; School B: grade 6, 7 and 8; School C: grade 12; School D: grade $10 \mathrm{~A}$ and $10 \mathrm{~B}$.

\section{Results}

According to M.J. Furlong (Furlong et al, 2015: Jones et al, 2012), in his research on positive psychology, there is no united definition of what would clearly describe the phenomenon of resilience (Svence, 2015) and related factor (life reliability, ability to adapt and renew the power of soul) interactions. Therefore, research was initiated to build that kind of concept that would express multidimensionality of vitality. As in the construct of vitality, one of the variables is health, and then in connection with the emotional and social intelligence of teenagers and youth, which is also correlating with the phenomena of vitality, a metaconstruct of covitality was made, which is the indicator of interaction of such positive health constructs as wellness, confidence and overall health synergy. M.J. Furlong emphasises that this research is directed at an optimal exploration of human functions, due to hypothesis that the first-order positive psychological constructs (Belief in Self, Belief in Others, Emotional Competence and Engaged Living) in combination builds the second-order synergic meta-construct covitality, which is a good tool for teenagers and youths' 
understanding of life quality level and prognosis of success and well-being in present and later life (Furlong et al, 2014). In Figure 1, the principle of M.J. Furlong's model is shown.

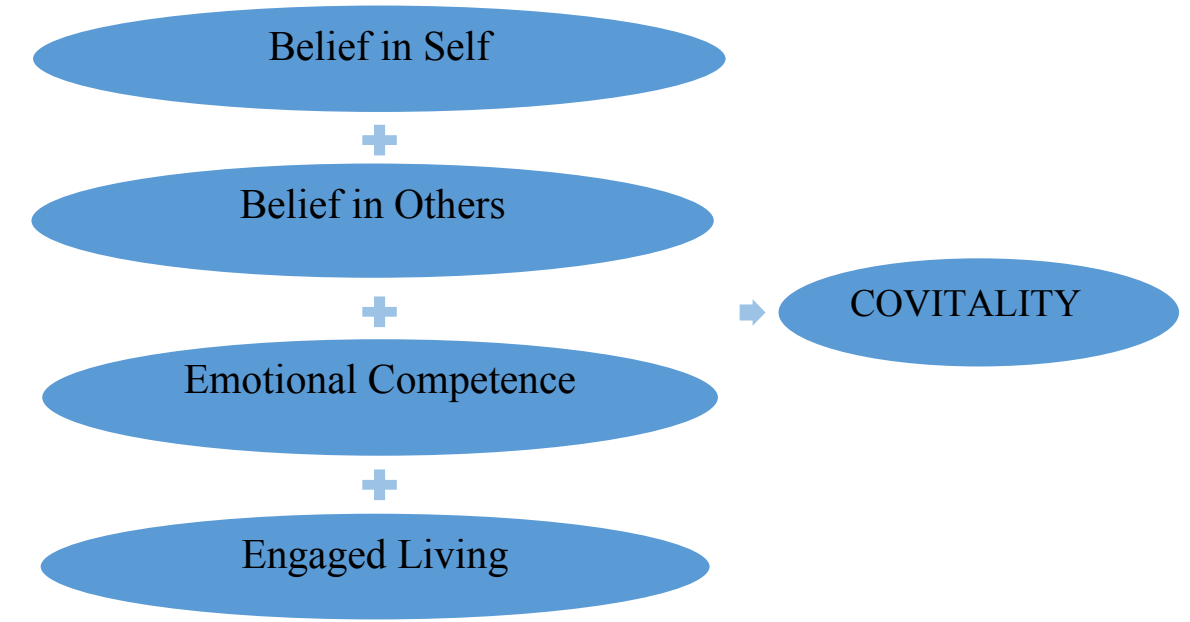

Figure 1. Model of M.J. Furlong's metaconstruct covitality

The term covitality is a concept to define social emotional health, which was proposed by M.J. Furlong during his research. This term is used in context of positive psychology and occurs only in Furlong's research group publications. Anyhow, it hasn't been found in various data bases and in other researches of the authors. This term can be considered as novelty in theory and practise of positive psychology. After analysing M. J. Furlong's definition of the metaconcept covitality, in author's opinion, this term could be translated in Latvian as social emotional health factor (in short version - SEH factor) (Timofejeva, 2015). Another variant of the translation could be synergetic vitality (Timofejeva, 2015). Based on Furlong's research group and other scientific research analysis, the author has made a hypothetical metaconstuct covitality model of interactions with other known psychological constructs (see Figure 2).

According to Furlong, research shows that all psychological constructs that build the meta-construct covitality model are correlated with high psychical health levels (Furlong et al, 2014). As shown in Figure 2, the analysis of known psychological constructs - emotional intelligence (Андреева, 2010; Дегтярев, 2012; Робертс et al, 2004), vitality (Александрова, 2014) and social competence (Каменская, 2012; Сулейманов, 2012) - also shows that harmonic progress of each category is the condition for good health. It can be considered that good level of synergetic meta-construct covitality indicator can show also good level of psychic health.

Based on Furlong's conclusion, as well based on the analysis of psychological phenomena that can be considered as forming factors of the meta-construct covitality, the author has proposed a hypothetical theoretical model (see Figure 3), which includes covitality precondition and possibilities dependent on covitality level development. This model could be improved and used. But the main fact is that big reserves of vitality and confidence, emotional and social competence, increasing in synergetic interactions, overall allow people to grow with harmony and develop productively. Respectively, if the precondition has a negative tendency, then it is more difficult to get a high covitality level for a young person. Therefore, the evaluation of covitality level with real teenagers and youths' social and emotional health aims to understand the situation and find out risk groups that need help (Lenzi et al, 2015), as well as potential leaders, high class specialists and, most importantly, people who are able to develop themselves. 


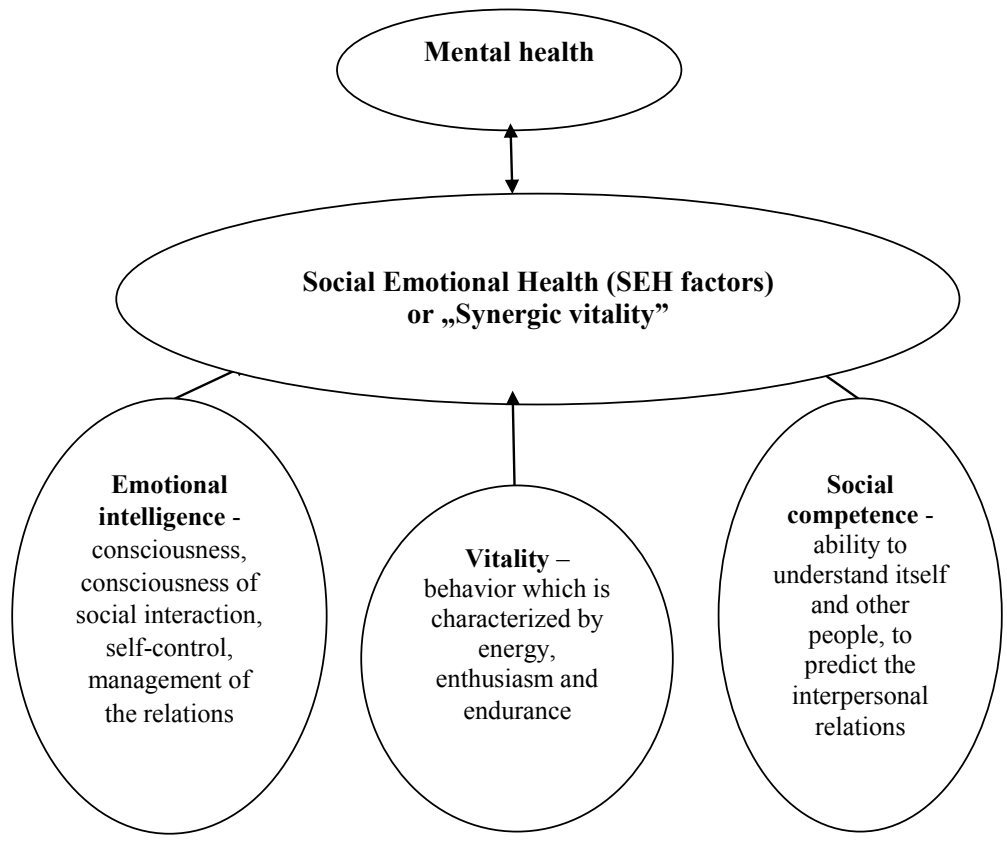

Figure 2. Author's theoretical model on social emotional health connection with similar psychological constructs (Timofejeva, Svence, Petrulite, 2016)

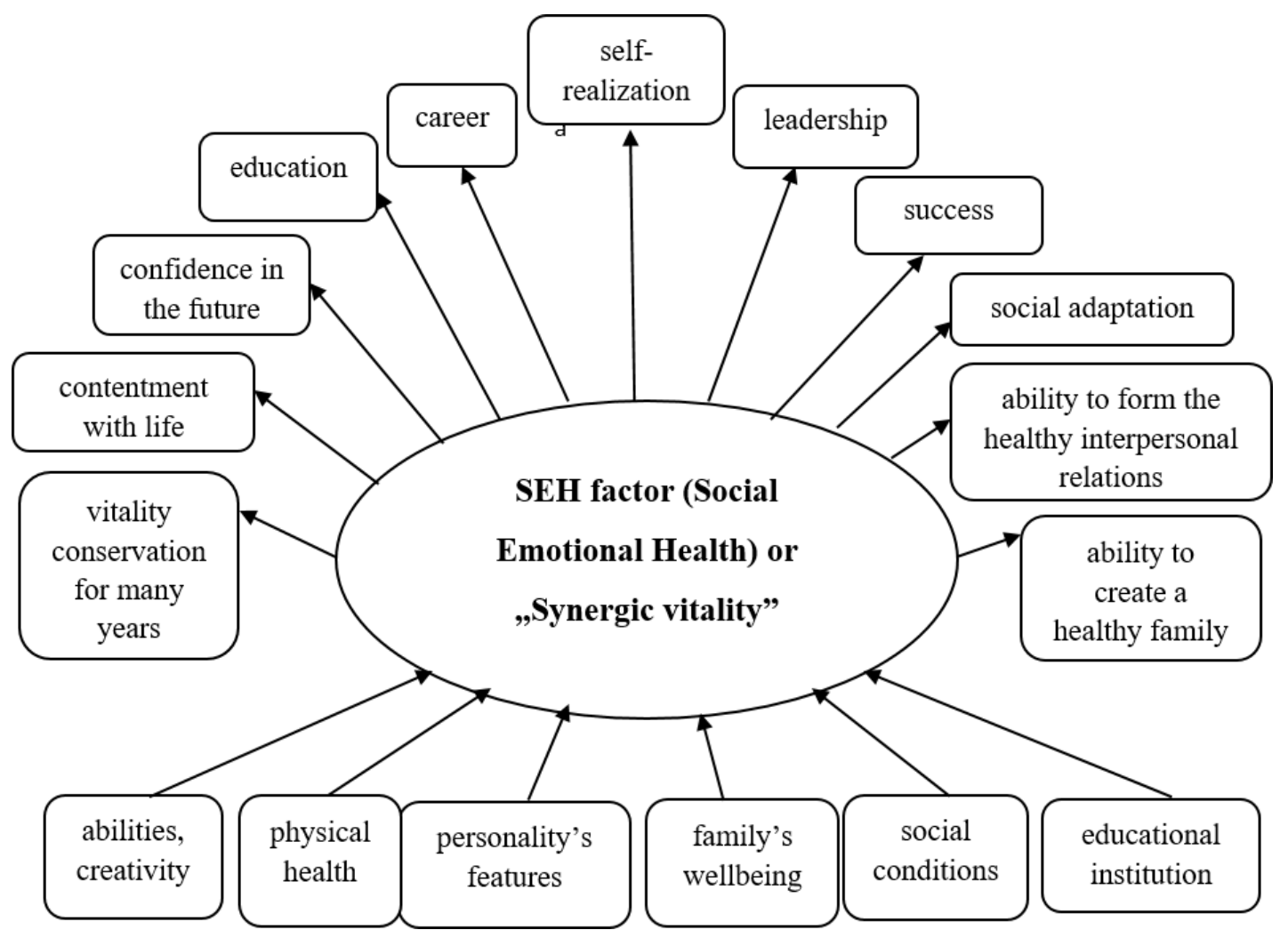

Figure 3. Author's theoretical author model (Timofejeva, 2015) about other variables influencing SEH factor and variables depending on the SEH factor; the psychosocial opportunities depending on SEH factor level (Timofejeva, Svence, Petrulite, 2016) depending on the SEH factor; the psychosocial opportunities depending on SEH factor level (Timofejeva, Svence, Petrulite, 2016) 
The overall statistical indicators of the control of the research methodology in teenagers and youth in the survey are shown in Table 2.

Table 2. Covitality (SEH factor) psychometrical indicators for all selection

\begin{tabular}{|c|c|c|c|c|c|}
\hline Indicator & Mean & SD & Cronbach's alpha & Skewness & Kurtosis \\
\hline $\begin{array}{l}\text { Covitality } \\
\text { (SEH factor) }\end{array}$ & 105.38 & 14.27 & 0.85 & -0.69 & 1.43 \\
\hline
\end{tabular}

Table 2 data show that, in general, the probabilities distribution of the meta-construct covitality (SEH factor) indicator in this selection can be considered as close to normal.

In this research, the covitality (SEH factor) as a psychometrical indicator can be compared with the results from various countries and social cultural groups obtained by various researchers. Table 2 shows that the methodology of 'Social Emotional Health Survey - Secondary' (SEHS-S) in the selected research group turned out to be trustworthy with Cronbach's alpha score of 0.85. But in Furlong research group's analysis, this indicator is much higher at 0.95 (Furlong, 2014). Yet, it is necessary to understand that the choice of respondents in his analysis was much higher. The average amount of covitality (SEH factor) in this research (105.38) is almost the same as the average amount (105.29) in Furlong research group's analysis of Latin American respondents (Furlong, 2014). The standard deviation in this research is much smaller than what has been showed by the authors of the methodology (Furlong, 2014). It is shown that in this research, the different meanings of covitality (SEH factor) indicator are more grouped around the mean indicator. The skewness indicator is close to the one shown in the researches by the authors of the methodology and indicate normal distributions. Kurtosis in this distribution is less than 3, which also suggests that this distribution is acceptable to the norm regularities. Therefore, the results in this research are in agreement with the results that were made in other socio-cultural respondent selections by the authors of the methodology.

As results show in Figure 4, almost 60\% of the respondents' covitality (SEH factor) indicator is higher than the average. In the selection, the respondents' social emotional health in general can be considered to be satisfactory. M.J. Furlong emphasizes that his research team's studies have shown that if the respondents' covitality rate is higher, the more often these respondents characterise their well-being with a statement, 'My life is going well' (Furlong et al, 2014).

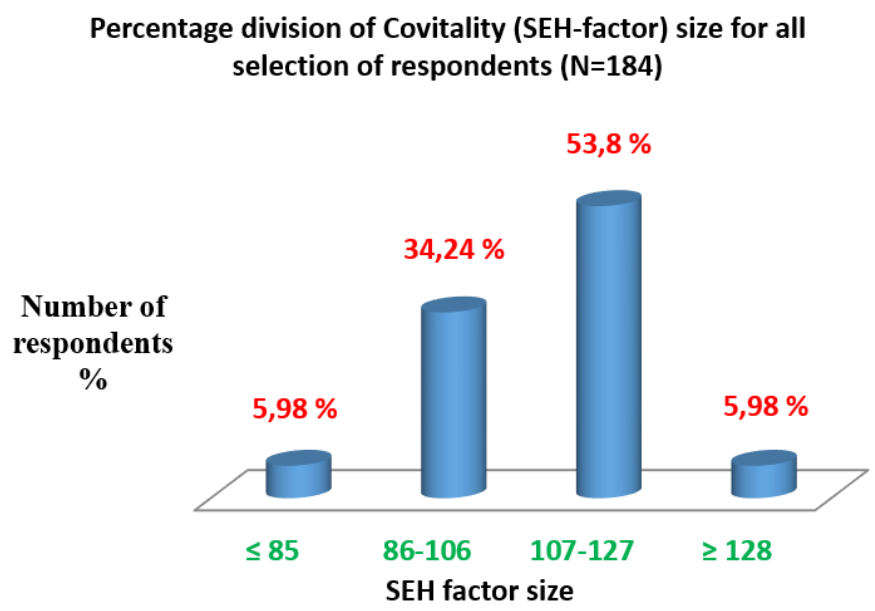

Figure 4. Percentage-wise division of respondents in four groups, depending on covitality (SEH factor) indicator size

The results could determine the risk group - respondents whose covitality (SEH factor) is less than 85 points. The causes for the reduced level of this factor may be different, but it is a signal that these teenagers or young people must be given special attention, as they may have weak health, learning difficulties, depression 
symptoms or any other negative social and psychological factors, for example, in family. In addition, they may be prone to deviation behaviour, drugs and unsocial tendencies. But an individual school psychologist should be working with a risk group of respondents, because the reasons for the negative tendency signs can be very different in each case.

Also, special attention should be given to the respondents group with very high covitality (SEH factor) indicator, because these may be people with high vitality, high capabilities and characteristics. The respondents should be given more opportunities for fuller realisation of their potential.

The sample was analysed according to the mixed characteristics of different variables: sex, age subgroups:

1. Based on sex division. Results of calculation are shown in Figure 5.

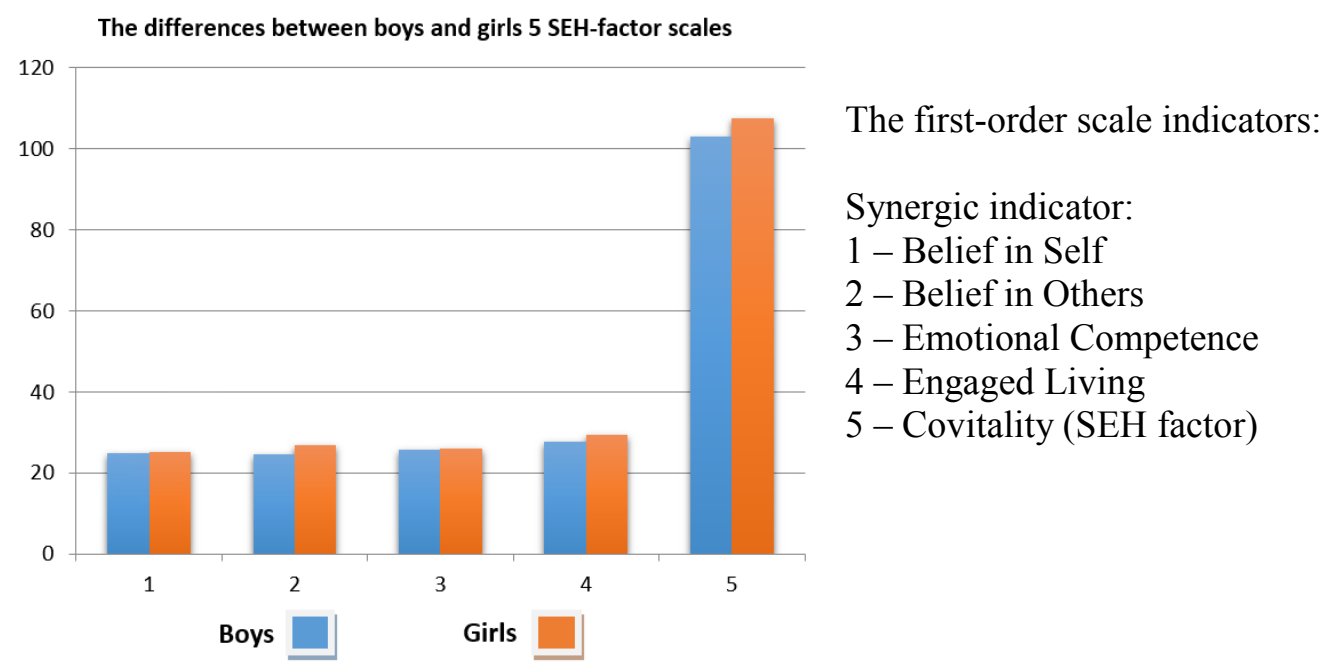

Figure 5. The differences between boys and girls on five SEH-factor scales

A statistically significant difference between boys and girls is formed between the entries of constructs of Engaged Living and Covitality (SEH factor), with $p<0.05$. In Furlong's studies, it was noted that the 'Social Emotional Health Survey - Secondary' (SEHS-S) methodology is the universal definition of gender indicators (Furlong et al, 2014). Therefore, it may be used, without restrictions or clarifications, with both girls and boys. Similarly, Furlong's studies revealed that girls showed higher rates of emotional competence and confidence than boys. But boys have higher rates of confidence about themselves (Furlong et al, 2014). In the current study, unlike Furlong's results (Furlong et al, 2014), it is observed that for the girls the firstorder and the meta-construct covitality (SEH factor) social emotional health indicators are higher. Furlong's studies demonstrate that the methodology 'Social Emotional Health Survey - Secondary' (SEHS-S) is trustworthy for all the teenagers and young people in all age groups (Furlong et al, 2014). Now, we will take a look at whether there are significant differences in the methodology 'Social Emotional Health Survey - Secondary' (SEHS-S) between the three research age groups, as well as between schools and between classes of each school.

2. According to the indication of age subgroups. The calculation results are displayed in Figure 6 . The difference between the different age group indicators was not statistically significant at $p>0.05$. 
SEH-factor indicators of three age subgroups

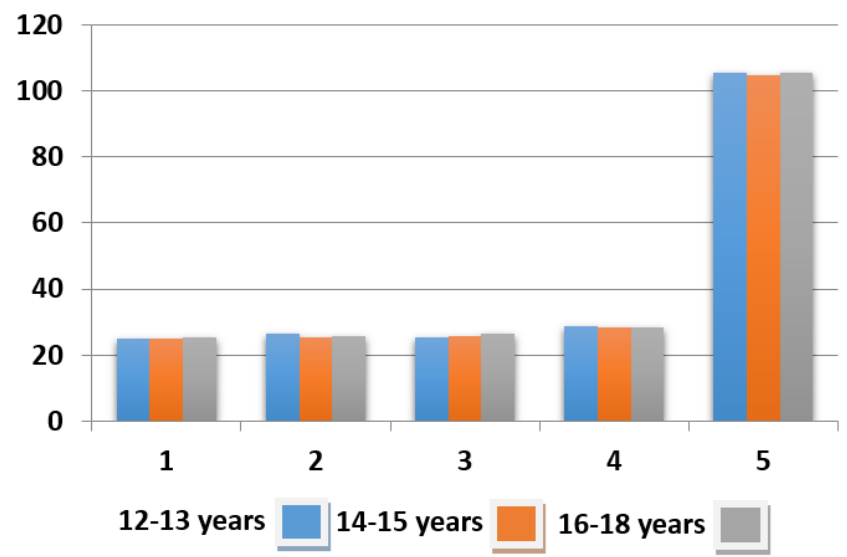

Figure 6. SEH-factor indicators of three age subgroups
The first part of the scale indicators:

Synergic indicator:

1 -Belief in Self

$2-$ Belief in Other

3 - Emotional Competence

4 - Engaged Living

5 - Covitality (SEH factor)

\section{Conclusions}

Furlong's methodology 'Social Emotional Health Survey - Secondary' (SEHS-S) is an original and, for the first time in psychology, an adapted detection tool for teenager and youth socio-emotional health metaconstruct covitality, where the indicator covitality combines in synergic interaction of positive socioemotional health psychological constructs Belief in Self, Belief in Others, Emotional Competence and Engaged Living.

From the terminology aspect, the new psychological concept covitality can be interpreted as the social emotional health factor (SEH factor) or as synergic vitality. According to the theoretical source analysis, a hypothetical model has been developed by the author for determining the adolescents and youths' social emotional health (SEH factor), where further research defines other mixed variable factors, which may affect the SEH factor development, on the one hand, and predict the possibility and improve good personal achievement opportunities later in life, on the other hand. The meta-construct covitality is associated with such mental constructs as emotional intelligence (Zeidner et al, 2003), vitality (Armett, 2005), social competence (Deci, 2008; Davis et al, 2014) and interacts with the construct psychical health (WHO, 2014).

The psychometric control of psycholinguistic conformity of the translation of the methodology 'Social Emotional Health Survey - Secondary' (SEHS-S) in the Russian language showed that the coherence of test's paragraphs is sufficient to consider this methodology's version as reliable and used in following studies.

The study of main selection ( $n=184)$ showed that the confidence level is high (Cronbach's alpha $=0.85$ ), the distribution of the sample probability density is normal; the statistical data of the conducted study are sufficiently in conformity with the results from studies of the authors of the methodology (Furlong et al, 2015). The risk group of respondents (with low SEH factor) was detected, as well as the group with potentially excellent characteristics (with high SEH factor), which could help the school counsellor to develop specific measures to help the group with low SEH factors and give more opportunities for development for the group with high SEH factors. It was found that the methodology can be also applied for the determination of statistical indicators in both groups and in the individual socio-emotional health of individuals, there is a statistically significant difference between boys' and girls' SEH factor indicators: all indicators of the girls are higher. There were no statistically significant differences in SEH factor indicators among respondents of three age groups, and it also shows that at least in the case of this sample research, the methodology can be considered as an appropriate psychometrical instrument for these age subgroups.

But it must be admitted that the given research has some limitations: the sample size of respondents (the authors of the methodology conducted a survey with much larger respondent groups using an average of 4000-6000 of respondents, Furlong samples (2014)); the study involved only teenagers and youths, with 
Russian as their native language. Therefore, there is currently no information about what could be the result of SEH factor of adolescents whose mother tongue is Latvian, as well as of teenagers and young people of other nationalities living in Latvia. A more precise approbation of the methodology would require much more wider survey of respondents in Latvia 's cities and regions, including not only general education schools, but also other types of educational institutions, as well as organisations and institutions where different type of activities are carried out by adolescents and young people.

\section{References}

Arnett, Jeffrey Jensen (2005). The Vitality Criterion: A New Standard of Publication for Journal of Adolescent Research. Journal of Adolescent Research, Vol. 20 No. 1, 3-7

Davis, Sarah K.; Humphrey, Neil (2014). Ability versus trait emotional intelligence: Dual influences on adolescent psychological adaptation, Journal of Individual Differences, Vol 35(1), 54-62.

Deci, Edward L. and Richard M. Ryan, (2008). Self-Determination Theory: A Macrotheory of Human Motivation, Development, and Health. Canadian Psychology, Vol. 49, No. 3, 182-185

Furlong, Michael J. (2015). Social Emotional Health Survey System. University of California, Santa Barbara Center for School-Based Youth Development Counseling, Clinical, and School Psychology Department, http://www.michaelfurlong. info/social-emotional-health.html

Furlong, Michael J. (2015). Psychological Health of Adolescents: Comparative Study. Letter to Professor Ala Petrulite, Lithuanian University of Educational Sciences

Furlong, M. J., R. Gilman, \& E. S. Huebner (Esd.) (2014). Handbook of Positive Psychology in the Schools (2nd ed.). New York, NY: Routledge/Taylor \& Francis. Covitality: A Synergistic Conception of Adolescents' Mental Health

Furlong, M. J. Sukkyung You, Tyler L. Renshaw, Douglas C. Smith, Meagan D.O'Malley (2014). Preliminary Development and Validation of the Social and Emotional Health Survey for Secondary School Students. Soc Indic Res 117, 1011-1032

Furlong, M. J. (2014). Research and updaded information about the system: Center for School- Based Youth Center for School-Based Youth Development, University of California Santa Barbara http://michaelfurlong.info/research/covitality. html

Furlong, M. J., Dowdy, E., Carnazzo, K., \& Kim, E. (2014). Covitality: Fostering the building blocks of complete mental health, http://www.researchgate.net/publication/270571062

Furlong, Michael Erin Dowdy, Katherine Carnazzo, Bibliana L. Bovery, \& Eui Kim (2014). Research-Based Practice Covitality: Fostering the Building Blocks of Complete Mental Health, http://www.nasponline.org/publications/cq/42/8/covitality. aspx

Jones, Camille N. Sukkyung You, J. Furlong, M. J. (2012). A Preliminary Examination of Covitality as Integrated Well-Being in College Students Soc Indic Res DOI 10.1007/s11205-012-0017-9

Lenzi, M. Furlong, M. J, Dowdy, E. \& Jill Sharkey, (2015). The Quantity and Variety Across Domains of Psychological and Socia Assets Associated With School Victimization. Psychology of Violence, Vol. 5, No. 4, 411-421

Svence, G. (2015). Dzīvesspēka kategorija pozitīvajā psiholog̣ijā. Attīstības iespējas. Zinātne, Rīga, 160 lpp (in Latvian)

Timofejeva, T., Svence, G., Petrulīte, A. (2016). Maikla Dž. Furlonga sociāli emocionālās veselības koncepta teorētiskā un praktiskā izpēte pusaudžu un jauniešu izlasē. Rīgas Pedagoǵijas un izglītības vadības akadēmijas XI starptautiskās jauno zinātnieku konferences rakstu krājums, Rīga: RPIVA

WHO (2014). Mental health: strengthening our response http://www.who.int/mediacentre/factsheets/fs220/en/

You, S., Furlong, M. J., Felix, E., \& O’Malley, M. D. (2015). Validation of the Social and Emotional Health Survey for five sociocultural groups: Multigroup invariance and latent mean analyses. Psychology in the Schools. Advanced online publication. doi:10.1002/pits

Zeidner M., Matthews G., Roberts R.D., McCann C. (2003). Development of emotional intelligence: Towards a multilevel investment model // Human Development, 46. P. 69-96. 